This is the author's final, peer-reviewed manuscript as accepted for publication. The publisher-formatted version may be available through the publisher's web site or your institution's library.

\title{
Fear and loathing in the fog: the perceived (and persistent) vagaries of tenure standards among mass communication professors
}

Thomas Gould

\section{How to cite this manuscript}

If you make reference to this version of the manuscript, use the following information:

Gould, T. (2011). Fear and loathing in the fog: The perceived (and persistent) vagaries of tenure standards among mass communication professors. Retrieved from http://krex.ksu.edu

\section{Published Version Information}

Citation: Gould, T. (2011). Fear and loathing in the fog: The perceived (and persistent) vagaries of tenure standards among mass communication professors. Publishing Research Quarterly, 27(1), 36-53.

Copyright: @ Springer Science+Business Media, LLC 2010

Digital Object Identifier (DOI): doi:10.1007/s12109-010-9195-y

Publisher's Link: http://link.springer.com/article/10.1007/s12109-010-9195-y

This item was retrieved from the K-State Research Exchange (K-REx), the institutional repository of Kansas State University. K-REx is available at http://krex.ksu.edu 
Fear and Loathing in the Fog: The Perceived (and Persistent) Vagaries of Tenure Standards Among Mass Communication Professors

This research started as an inquiry into how "born-online" publishing is valued (or not valued) by tenure committees. More than 2,500 professors at large and small universities and colleges across the country were asked to respond to an online survey centered on measuring the levels of acceptability amongst their faculty for new journals created on the web with no print antecedents. More than 500 did, and almost 400 completed the survey. Yet, the responses to questions regarding the tenure process-a last minute addition — turned out to be at least as interesting. In addition, we received dozens of emails from those faculty members choosing to opt out of the survey, presenting a fascinating range of emotions running the gamut from confusion and fear to visceral anger.

It could be argued (and has been argued) that the lack of a clear set of standards allows tenure committees to respond to each candidate's own style of research. That is, in the mindset of some, flexibility is good. Flexibility avoids harsh, immovable standards that might lead to a possible disqualification of a worthy candidate. At the same time, however, some candidates—at least as exhibited in this survey—-feel the vagueness of the standards and the process of evaluating those standards might allow for personal, nonscholarly bias. Their concerns are without some foundation. This is, after all, a discussion and debate that has raged over generations of academia and is very likely to continue to do so. (Bradley 2006, 1; Carter 1991; Stevenson 2010, 1; Verrier 1992) 
So much is at stake: tenure provides to the researcher and educator protection, usually, from random censure and dismissal related to controversial works. It allows professors to present controversial ideas without fear of retribution. Of course, critics note that it is, in some cases, an opportunity to "coast" to retirement, with tenured professors putting forth little or no effort.

Whatever the consequences of tenure, it is, in itself, a major hurdle for all academic professors. In many ways, it holds equal—if not higher status—status of the annual evaluations of department chairs. Tenure committees are expected to be the guardians of a particular field of research and protectors of the standing and reputation of the department and college. Decisions of tenure cannot be taken lightly. It should not be assumed that all negative tenure votes are based on personal bias any more than all positive votes are based on deserving faculty work.

It is a system that had been a lightening rod within academia for as long as it has existed. And the questions that are routinely raised demand attention and serious consideration. Should tenure standards be explicit? Should candidates be made clear on precisely what is expected for tenure? Should the committee be allowed to use unstated standards? Should the entire process be kept in the shadows, that is, anonymous? Should tenure-track faculty be mentored along the way or are they expected to rise to the standard "on their own," as have many prior faculty candidates.

What is at question here is not just an institutional tradition that may have run its course and is certainly being overtaken by the tides and demands of new media and new technologies. What is in play is how we, the academy, going forward will judge the good works from the not-so-good works from plainly bad scholarship. This is not, or at least 
should not be a matter of style (as in "you cannot publish in a law journal unless you are trained to write like a lawyer, regardless the value of your research"—which may be truer than not). Nor should the argument succumb to the vagaries of "more speech is better than less speech," though the proposition has its strong points. Certainly we can hide behind tradition, though it is not a particularly strong position as it once was. One only has to consider the current state of newspapers to realize that relying on tradition to steer readers to traditional methods of accessing and digesting news may not be a good idea. Yes, the tenure process has insured that some of the best researchers have been moved forward, while the rest, well, go do something else, like, perhaps, work at a lesser university, community college or teach-only institution. But has the tenure process really lived up to its reputation? And are community colleges really stuffed full of tenure rejects?

While we do not pretend to address the issue of tenure-less professors at community colleges (worthy as it is) in this work, we do wish to suggest that the belief by tenured faculty that they a pirori know what is the undefined best for the "little people," also equally derisively called "junior faculty," is has generated unnecessary fear and doubt among even the best candidates for the lofty status of "associate."

Perhaps it is time to step back, examine the history of the tenure process—as much as a such a purposely vague, purposely secretive process can be plumbedconsider then its standing as suggested in a survey of mass communication faculty, and finally suggest a new, less vague and more accurate method of separating the wheat from the chaff (and actually keeping the wheat)—apologies to Mr. Stevenson. (Stevenson 2010, 1) 


\section{Where we are now (and how we got here)}

Stories abound—especially in blogs and other online platforms—of rough treatment at the hands of tenure committees and department faculty regarding the, attimes, opaque steps that raises a professor from assistant to associate. Sometimes these stories refer to seemingly arbitrary changes in tenure standards: "They did this without informing anyone who would be affected by it, or the tenured faculty, for that matter. This means that probationary faculty who did what they were asked to do, and even those who might have looked beyond their department for a second opinion as to how to meet the bar, were hammered. Tenure denials went from ten percent to forty percent. Twothirds of the women up for promotion were denied."(Tenured Radical 2008, 1)

Sometimes the stories relate political decisions trumping scholarly standards: "One of the frustrations of administration is that process is grievable [sic] but judgments aren't, so when people disagree with judgments, they attack process. ("This is an outrage! How was this decision made?" or its close cousin "It isn't so much what they did, but how they did it.") In many cases, the same people who routinely decry administrative paperpushers are also the first to allege procedural irregularities when something happens that they don't like; they rarely see the contradiction. Since many processes are relatively cutand-dried, the way to attack them is through character assassination-allege bias against whatever trait is at hand. And it's incredibly hard to prove you weren't thinking something, no matter how far from your mind it actually was." (Dad 2008)

And, sometimes the process appears to favor one demographic over another:

"Findings indicated that females were more likely than males to mention the influence of 
parental expectations on their emerging career interests and appraisal of their potential; that many participants had a preoccupation with knowing where they stand in the tenure process and a craving for specific indices; that most departments are characterized by a culture of competition; and that, although males and females both struggle with the issue of social expectations, males appeared more likely to arrive at a decisive stand and point of resolution while females continually feel ambivalent." (Verrier 1992)

And, contrary to the popular notion that tenure is a one-time and done decision, more attention is now given to evaluation of a tenured professor's on-going research and teaching activities. The concept of "Retired In Place" (RIP) is giving way to ongoing reviews and assessments. "During this period of re-definition of tenure, which includes the contentious issue of post-tenure review, it is important that the process for tenure evaluation is well understood and fairly executed. The tenure process is not a one-time event but a process that begins at the time that the job description is formulated and ends with retirement from the profession." (Bradley 2006)

It is an ironic turn that tenure review itself is undergoing (and has always undergone, some would posit): a sort of review of tenure. It has never, historically, tended to remain in one place under one standard for long. Important historic moments have occurred, whether it is the adoption of certain standards by the ruling authority, be it the church or royalty, or the evolution of the university in Paris and Bologna, or even further back, the lesson seminar entities in Greek and Islamic histories. Tracking tenure, however, is less about the standing of the university as it is about the precept of an independent scholar, much as a successful surgery is far more important to the patient (and doctor) than the hospital in which it takes place. 
While tenure has shifted over time, no period has presented its largest challenges as now. Beginning in the mid-1990s, a combination of rapid technological advances combined with shrinking state funding and university budgets has recast the concept of tenure. Its place as the best protection for independent scholarship has now shifted to a view—especially among funding groups such as state legislatures—-that tenure is an unaffordable privilege for a few. As politicians increasingly use The University as a straw man to capture votes, scholars also face pressure from accreditation groups to reverse declining educational standards, as well as adopt improved teaching techniques to create higher student learning outcomes. Salaries are frozen, faculty lines left unfilled, and donor support dwindling. To be a scholar in this country at this time is, perhaps, as marginalized, and unpopular position that tenure for researchers has faced in decades, perhaps centuries. Perhaps.

Yet, a close reading of history would reveal that the university's tenure system has always drawn more than its fair share of criticism. From church purview, to royal patronage, to scholarly overview, some observers have always considered the system of who is acceptable and who is not as elitism based on subservience to existing (stale?) standards defined by the academy. What is not always noted is that tenure, in one form or another, goes as far back as Athens, far earlier than the creation of The University in the Middle Ages.

The History of Tenure Review: Prior to 1600

From one perspective, this is well-trod ground. Discussions of the influence of popes, kings, and other medieval power brokers on who was allowed to teach and 
conduct research in monasteries and courts are numerous and well-cited. The same can be said regarding the creation of universities, whether those that came to be in Paris or Bologna. We would refer the curious reader to these powerful works for a summary of what happened where and when in terms of academic tenure in the times prior to Gutenberg. (Fuhrman and Lazeson 2005; Hamilton 2002; Joughin 1969, 374; Hofstadter and Metzger 1955; Keast and Macy 1973, 276; Hannam 2009, 12; Plater 1995; Clark 1987; Fuchs 1963; Halse and Lilien 1986; Post 2003) Indeed, some of these provide excellent summaries, in great detail, of tenure practices following the creation of the printing press.

It is not the intent of the author to revisit all of these works, but rather to examine a particular part of the academic tenure practices of those times that are of some importance today, specifically, the clarity of what research publishing was valued and/or allowed. This "valued and allowed" dichotomy is of importance, for over time the creation of works that might be published increased faster than the acceptance of works for publishing. It is this gap between the almost absolute certainty that a researcher publishing in 1500 possessed, for instance, versus the degree of confidence a researcher publishing in 2000 might exhibit. The almost complete control of the publishing process in Medieval times by the church and/or state — depending where in Europe the researcher resided at the time — was far clearer and straightforward as compared to academic practices in modern times. This is not to suggest that there were not issues, such as the dismissal of faculty speaking openly about contemporary social ills, such as was the case with the firing of Scott Nearing by the Wharton School in 1913(Sass 1982). It is to argue 
that the clarity of what was "valued and allowed" was often stated via edicts and papal bulls, versus the, sometimes, vague terms contained within tenure standards today.

As noted by Hannam, it was the university itself as a concept that was uniquely European and uniquely constructed to be ruled by the scholars that comprised it (Hannam 2009, 12). Prior to the creation of universities, scholars were answerable to a single entity or immovable religious strictures.

Previous models of education and research establishments has existed, such as the Museum of Alexandria answerable to the king, the schools of Athens answerable to a single scholar and the madrasas of Islam whose activities were rigidly limited by religious law and the wishes of their founders. (Hannam 2009, 2)

As noted by Clark, "the Church exerted a dominating authority and pervasive influence over culture and society in the Middle Ages," and outside the "soaring cathedrals and cloistered monasteries," education was the activity of clerics. (Clark 1987, 669). The pathways to success in the Middle Ages almost always involved strict adherence to monastic edicts. This was especially true in Northern Europe (Clark 1987, 670).

The creation of secular schools, especially in Italy in the twelfth century, shifted power away from the church and into the hands of a new, rising "lay-spirited" middle class. The University of Bologna, "known for its secular, democratic, and egalitarian attitudes," (Clark 1987, 671) was created in response to the need among teachers and students to feel free to study outside of the strict terms set down by religious edicts. Yet, even here, and in Paris, the rise of this innovative educational model — the university- 
still sought the approval of Rome and the Pope. Teachers were expected to follow the strict course plans provided to them. (Clark 1987, 672). And successful students, who flocked to Bologna from all over Europe despite the dangerous hazards of travel at the time, could look forward to careers in politics, city administration, or the judiciary.

It was at Bologna at that what might be the first example of a tenure process was adopted. The doctoral candidate's mentor would be present him to both an archdeacon and the faculty of the college, followed by an examination conducted by two of the faculty members. The full faculty would then pose more questions and comments. If a majority of the doctors then voted to accept the candidate, he would be promoted. The new doctor would then present a "doctoral disputation" at the cathedral, where the degree would be official conferred. (Clark 1987, 700).

As noted by Clark and others, the expectation of these examinations was that the candidate could recite the accepted standards of understanding within one or more of four areas of learning and research: law, medicine, theology, and liberal arts. These new faculty members were expected to attract fee-paying students, the life blood of these rising universities, and those professors who were most successful were highly prized and in great demand.

Interestingly, the form of the examinations involved the challenging of arguments made by candidates. In the case of doctoral candidates, a small group of chosen faculty members would examine a candidate's written proposal, judging it for both the work's adherence to canon law as well as its scholarly nature. If heretical statements were found, the candidate would have the opportunity to correct the errors, or, in rare cases, deny the statements were in error. Notably, contrary to the commonly held belief that such 
statements lead to instances of candidates being excommunicated, a candidate found of making heretical statement—and willing to correct or successfully dispute the errors— faced no long-term damage to their careers. (Hannam 2009, 7). But such promotion was not an assurance of academic freedom; that concept would be part of a movement that occurred several centuries later in Northern Europe.

\section{The Modern Landscape of Academic Tenure}

As we, the university, moved further and further into the realm of the professional professoriate, rules arose to cover all manner of possibilities within a community run by faculty. One of these was the matter of how a researcher might be provided the protection from "outside forces" to the extent that provocative ideas might be presented without fear of reprisals. One might call this the Galileo Rule, in respect to science being bounded by theological rule.

The more scholastic, less ideological model, it was thought, would allow the ideas of round and flat worlds to co-exist, at least as much as arguments could be made in support of each. Researchers could not only suggest provocative ideas, but they could research unpopular subjects, all without fear that they would be punished by some nonscholarly entity, such as the church. What took the place of the Pope would be a bank of peers, fellow scholars, who would offer an unbiased, clear-cut analysis of the value of the researcher to academia.

It is not the view of this researcher, however, that this lessening of religious constricts (Hofstadter and Metzger 1955) (which exist in some places in this country to this day) resulted in a sudden golden age of academic freedom. Nor does this suggest that 
this freedom suddenly sprung forth (consider the case of Willard C. Fisher in 1931) (Metzger 1973,146).

However, it can be argued that researchers in the 16th Century might have had a better idea when they were trending on thin ice than academics do today. In a religious system, the lines are brighter, and the penalties and cures for violating the rules of the theocracy better well known. The rules of academic conformity today, generally involving "objections to the economic or political views of faculty members," have been extended to include utterances regarding "sex, or literary works which have been deemed offensive" (Fuchs 1963). The exact nature of what constitutes such offenses are not so clearly stated or widely known. It is not unlike walking through a minefield unaware not only of the location of the explosive items, but even of their very existence.

But it is not the intent of this author to plough again the fields of discourse that have focused on these issues, dealt with so ably by others (Plater 1995; Post 2003; Metzger 1973; McPherson and Schapiro 1999; Seipel 2003; De George 2003; Connolly 2000; Thorens 2006; Plater 2008; Goldin and Katz 1999; Resnik 2010). Nor is it the intent of this essay to suggest that politics, religion, and personal biases can ever be wholly removed from the academic tenure process. After all, one person's carefully measured opinion is to another a knee-jerk, unfounded bias.

It is the intent to offer a quick take on where at least one part of academia - mass communications - resides in the spectrum of tenure review, and to posit from this some curative options. We do, of course, give great due to what happened to the tenure process in the last century. The path that higher education took in the latter part of the 19th Century and into the early 20th Century that led modern higher educational institutes 
away from dull strictures of rote learning to the far more exciting and lively realm of the generation of ideas, as outlined by Connolly. The path was a crucial departure from a clear syllabus of specific rules regarding to "perceptive importance of religion, the disciplinary advantages of the classics, and, above all the waywardness and immaturity of youth that classed for precepts and discipline." (Hofstadter and Metzger 1955, 279). The new university of the early 20th Century was intended to be a place of thought, and, most important to this essay, a place of tenure as a mechanism framed to protect the freedom of speech guaranteed to the general populace via the Constitution, but not as yet extended such freedoms to academic faculty. We draw broad strokes here, of course, but the rise of the concept of "academic freedom" and its relationship to "academic tenure" as described by the newly created American Association of University Professors (AAUP) in 1915, 1940, and other occasions would on the one hand certainly lead to more lively discussions, but also, unfortunately, to far more vague standards. Within a university structure largely influenced by Kant's precepts regarding the establishment of the "higher faculties," the stricture on a freedom to speak to one's beliefs within academia would shift from government and church to the university, to cohorts within specific disciplines. We saw the autocrats and theocrats abolished, but created a new class of judges who were charged with the responsibility of protecting progress: the faculty of the colleges within these institutions. The result is a structure that exists to this day, one that promises academic freedom, a freedom that is "necessary to safeguard the search for truth," but that, as noted by Connolly, may be "just so much window-dressing used to disguise the realities of entrenched privilege" (Connolly 2000, 75). 
What is suggested within this work (and others) is that the task of ensuring academic freedom is not complete, but merely rendered to a higher education bureaucracy composed of "special" elite faculty, tenured to provide judgments on others based on concepts that are not nearly so clear or specific as they were a few centuries past. Add to this the economic and inherent political pressures of our times, and you have, as outlined by Thorens, a landscape of constant strife between "the hegemony of the economic world and the large multinationals, more powerful than many countries" and the Academy, with its desire to protect the autonomy of the university stricto sensu (Thorens 2006, 108). This conflict between society and the university has and will always be with us, and, again as noted by Thorens, this may be desirable. Either way, "to the issue of academic freedom and university autonomy, there can be no definite and permanent solution" (Thorens 2006, 108).

But again, it is not the intent of the author to suggest either that the current system is irreparably flawed or that some magic wand exists to make tenure review a perfect measure of an academic's value to Society, whether that Society is within or without the university. It is, rather, to look at some steps that might be employed to move us a few steps down the road to a better, fairer, and more accurate measurement. If we first can agree that the ideal of Academic Freedom is fraught with "exceedingly fuzzy boundaries" (Post 2003), then we can then at least consider what could be done to bring those edges into sharper focus.

Issues Facing Tenure-Stream Faculty: The survey methodology and outcomes 
In 2009, emails were sent to more than 2,500 professors who were identified as teaching a mass communication course within a university or college in the United States. The email requested that the professors take an essay that dealt primarily with online journals, specifically the standing of those publications that were "born digital" and had never been offered in print form. While the results of the main portion of the survey proved to be very interesting (the single-digit acceptance of research published in bornonline academic journals), the response by more than four dozen professors (roughly $10 \%$ of the respondents) to a few questions regarding expectations for tenure were equally fascinating. The survey respondents (and two email respondents) expressed fear, worry, and outright rage regarding their school's tenure process.

These answers to questions regarding tenure committee expectations fell into two general categories: that the lack of specific tenure standards is purposeful in order to allow maximum flexibility to the candidate's favor, or to ensure a negative outcome. The first of these categories (to benefit the tenure candidate), included comments such as "Unfortunately, when I got to [the tenure] question of your survey I had difficulty completing it because I was required to discuss specific numbers regarding publication expectations and my department does not specify any number of publication expectations-I know this sounds vague, but our senior faculty has advocated that not specifying a specific number of research expectations in the different research categories (e.g., major publications, national/regional journals, national/regional conference presentations, etc.) allows for flexibility in evaluating and crediting faculty with their work." 
While the rationale of flexibility was not frequent in these voluntary comments, it would be unwise to think that many who completed the survey without offering comments would not agree. Allowing tenure committees the chance to weight each candidate is at the least acceptance that tenure itself is comprised of more than publishing. Yet, some academics fear that a lessening of the standards will result in an equally lessening of results. It is, as put by Ferris, a way to measure the future worth of a colleague. "The probationary period leading into the tenure decision then becomes one where coordination gains can arise from better measurement, evaluation, and integration of new faculty. It follows that tighter tenure standards require greater evaluation efforts with greater turnover and success should result in superior department performance" (Ferris and McKee 2002, 1).

Part of the argument for stricter standards is that publication be restricted to only the best publications. Measuring the quality of a journal, though, gets sticky. Some of the survey respondents took a swing at it, though, with many offering terms such as "peer reviewed" and "rejection rates." Several mentioned perceived journal quality as a valid guideline, while others suggested issues of possible legal considerations. One, in fact, addressed both of these areas:

"At the two Research 1 universities I've worked at, [a specific number of required journal articles] is, by design, never specified. The idea, of course, is that if someone said two per year was the magic number, tenure and promotion committees would have to approve anyone who went up with 12 articles, even if the articles were all in the Southeastern Ohio Journal of Speech Communication, rather than, say, Journalism \& Mass 
Communication Quarterly. In my unit, someone who had seven articles in Journalism Studies or Journal of Communication, with their $10 \%$ acceptance rates, would be viewed as far stronger than someone with 12 articles in Newspaper Research Journal. In addition, I think most units recognize that suggesting a specific number could put them in a tricky place legally, should someone who was denied tenure or promotion decide to sue."

Another respondent suggested the tenure process had created a cottage industry of publishing that was created and sustained not because of the value of the research, but the value of publishing to tenure and promotion. "It would be useful to know readership and impact of the articles. So many peer-reviewed articles end up having no impact. They're just part of the tenure/promotion machine. It feeds on itself." This is an interesting point and deserves further research. Have we created enough journals to satisfy a need to publish to attain tenure or a need to support and disseminate well-deserving research? Are we resisting creating new journal for fear the rejection rates will fall?

A few other respondents suggested that the degree to which an article is cited might provide a measure of the value of both that research and the journal in which it appeared. As one put it, "citation patterns are generally the most important indicators of the value of a journal, since they indicate the value of the articles that are cited." Of course, a frequent issue with citation rates is that bad research can be cited as an example of error, and yet, using the citation as a measure would mistakenly be taken as valuing that faulty research. 
Some respondents took a moment to comment on the trend of research online, and the tendency of researchers (especially younger ones) to look online first before drilling into restricted-access proprietary databases. (He and others 2007; Lawandowski and Mayr 2006; Madhaven, et al 2009; Wright 2004)

"I believe that print-only journals are irrelevant, since most of them are hardly ever read by anyone -- and rarely retrieved."

"All peer-review journals should be treated as equal. The criteria should be the same for online and print journals. All peer-reviewed journals should count equally."

"ALL [respondent's emphasis] journals should be available online -- and I believe exclusively so. The fact that we would differentiate online vs. print shows how out of step the academic institutions have become."

"There should be absolutely no difference in the aspects of a printed vs. online journal."

"I think administrators should value any journal available online more highly, as those journals actually forward what we espouse as a primary value and goal--making knowledge available. To everyone. Everywhere. Anyone who tried to devalue a journal for publishing in a new medium is 
a) reactionary, b) insecure and looking for reasons to denigrate other people's creativity (isn't it always easier to criticize than to create?), and c) ignoring our true purpose as researchers and educators. The Internet has the power to share knowledge even where dictators or poverty would close it out."

"[A well-known professor and online journal editor] used to say that publishing expectations of Journalism administrators were impossible, not because of workloads or ability, but because there was too little space in the available journals for our research. I would add that where science and business journals are usually well funded and libraries pay huge annual subscription fees for them (one biology journal is $\$ 3,000$ a YEAR!), journalism journals have not been. The online option permits more of the quality research out there to be published and shared worldwide."

We come away from these comments feeling the authors were expressing a defense of work published in an online journal by way of defending the journal itself, as its digital nature.

For some, the actions of the department chair on a personal level can spell doom in gaining tenure. "For my small private university, it's nothing to do with the journal, whether it's online or print or both, whether it's refereed or not, conference paper or panel presentation -- it's all about who the Dean likes and who he doesn't [like]." Such an unfair arrangement can be difficult, if not impossible to cure, in part because the tenure review 
is almost always conducted privately, with little or no reporting of what was found lacking in the application.

In other situations, the push-back from older faculty can result in a vicious environment.

"My Dean (BA) and Director (degrees only from this school) are so clueless to academe and so...defensive? provincial? inept?...that their requirements of us vary entirely based on whether we're in their tiny 'incrowd' or not. All PhD holders are treated as pariahs but expected to carry the rest of the faculty in ALL research publishing, while the MAs skate by."

Some suggested measuring the value of a published article and its journal by way of largely undefined terms such as "impact," "Some form of circulation figures," "standing," and "reputation," though none offered an idea how to weigh these against other standards. For example, circulation figures do not suggest readership, especially when that subscription is part of membership in a group within the Association for Education in Journalism and Mass Communication. Sign up for an interest group and you automatically get a print journal in the mail every quarter. Yet, interest groups might, logically, be in a better position to claim some readership from groups members than Journalism and Mass Communication Quarterly, which is automatically sent to all AEJMC members. As for "standing" and "reputation," much of this has more to do with tradition than performance, not unlike the royalty status of some individuals in countries with a long history of kings and queens. Finally, "impact" is, well, impossible to gauge, 
except over some extended period of time, and would seemingly have more to do with the research published than the tome in which it appeared. As one survey respondent noted, "an article in a good journal that no one cites does not make much of an impact." And another chimed in: "Measuring reputation becomes the difficult part, of course (impact measures have considerable lag)." The conclusion here might be that good research might improve the reputation of a journal, but the reputation of a journal should not automatically raise the value of the research contained within.

Finally, some simply threw of their hands and declared their ability to offer what their department's standards for tenure to be so vague as to be useless.

"I started taking this survey and realized I did not know most of the answers. There was never a choice that read 'it is not clear within our handbook' or some such thing."

Another simply noted: "I have no clue."

Leaving tenure-track professors to fend for themselves with little or no feedback is neither optimal nor as frequent as these comments might make it seem. But, clearly, it happens too often. Placing personal ego or negative feelings in the place of sound academic reasoning also has no place in the tenure process. It could be argued that this willingness to "misbehave" is linked to the anonymous nature of the process. It could also be argued that in a shrinking economic environment that most state schools are facing, petty bickering should not be unexpected. Whatever, the cause, it is at least clear that while not necessary a full-blown epidemic, the vagaries of the tenure process is unnecessary so and should be eliminated. 
The situation is further complicated by a lack of clear directives for tenure-track faculty (as noted in the survey results). Faculty in many schools simply lack and idea of what is expected of them.

The purpose of yearly evaluations and three-year reviews should be to give accurate and unvarnished criticism of a candidate's work. Mentoring systems should likewise closely monitor a probationary faculty member's progress (or lack thereof), which in turn should be reported to everyone on the committee and the candidate in a timely and clear manner. Yet such safeguards and checks are only fitfully applied. On many campuses, the third-year review is cursory and mealy-mouthed. A common outcome is the "problem" candidate whom nobody wants to deal with until the tenured faculty members and chair get a chance to hide behind an anonymous vote. (Perlmutter 2010)

Add to this the publish or perish pressure placed on faculty, especially those who seek to publish in areas and journals "outside" their Kantian academic areas, and you generate research that can be published, not always what should be published. As we increase the number of faculty globally, are we providing reliable outlets for their research?

\section{Issues Facing Tenure Candidates: The pressure to "properly" publish or perish}

A rising tide of entrepreneurialism is sweeping through universities worldwide (Wilson 2010). Faculty are expected to produce more research, receive more grants, and 
crank out better students. But, unfortunately, the environment that would make it more likely these goals would be reached is becoming instead a field of fierce competition. As noted by Wilson:

With standards for tenure at major research universities rising year by year, professors say academe has become such a pressurecooker environment that faculty jobs barely resemble those of a generation ago. (Wilson 2010)

Part of the pressure comes from the creation of more and more doctorates without an equal number of new positions being created in all fields. That is, while overall demand for new professors is expected to be up overall, in some areas, the growth is miniscule at best (Aylesworth-Spink 2010, 1).

The added numbers of new academics is also causing a log-jam in publishing, with the creation of new print journals almost at a standstill (Abandoning Print, 2008, 11). New journals are skipping the "print stage" and jumping directly online, which is good for new researchers, but not necessarily valued by traditionalists among tenured faculty. Thus, while the opportunity to publish in small, online journals may rising, it might cause some researchers to pause. The need to publish in the most prestigious journals is still present in most universities, regardless of whether the standard is driven by actual outcomes or personal biases.

\section{Issues Facing University Administration: The Race to the Top Ten}

I ran across an address some time ago by a vice-chancellor at a university in Virginia who suggested that all community colleges strive to be 4-year universities, and 
that all 4-year universities strive to be Research One universities, and that all Research One universities strive to be Ivy League universities, and that all Ivy League universities strive to be Oxford University. I thought it was clever at the time and think even more so now as the desire by every university to be ranked in the 10 of some field seems even more pervasive.

Anyone reading this could easily scan the conversation online that seems to just throb regarding the chase for the golden apple of academic stardom. Just employ the search terms "university pursues top-ten status" and the results will be convincing:

Phase II of Oregon State University's 2004 Strategic Plan for the 21st Century continues the University's ambitious drive to rank among the ten best Land Grant universities in the nation. This updated Plan builds on OSU's long tradition of excellence in education, research, and outreach - and on the significant progress arising from the initial Strategic Plan and the University's first university-wide capital campaign - to:

- $\quad$ Sustain and accelerate improvements in student learning and experience through creation of outstanding academic and student engagement programs;

- $\quad$ Align and strengthen innovative scholarly and research activities to continue discovering new products and technologies that generate economic activity; and

- $\quad$ Focus even more intently on enhancing OSU's ability to produce strategies and solutions for the most important - and 
intractable - issues facing Oregon, the nation, and the world.

(Office of the President 2010, 1)

The deep desire to be known as a top ten for something can lead to some rather odd pronouncements, such as suggesting that a university is the best north of one river and south of another. It is indicative, though, of the intense pressure on all universities to justify their existence and their worthiness in the area of grants: the mother's milk of all research and life blood of all universities. Without status, or so the old saw goes, there will be not grants, and without grants there will be no great research, and without great research there will be no students. It is an argument that is hard to gainsay.

Thus, with pressure applied, with the fate of an entire university bearing down on tenure-track researchers, you would believe that everything that could be done to encourage the best work would be a de facto activity at all universities. You would be wrong. As noted in the comments earlier, some faculty—at least in my field of mass communication—are adrift without a sail, up a river with no paddle. And while I am loathe to apply numbers to this, it is not a long reach to suggest that the roughly $10 \%$ of the survey respondents who offered comments are of some significance.

So what is to be done to right the ship? The first step might be to remove fear born of ignorance from the till and bring some element of clarity to the process of tenure itself.

Potential Solutions: Ten Ideas, Some Using New Media and Social Networks 
The primary question that all faculty must face is whether it is their intent to create successful tenured colleagues. Lacking a commitment to the idea that a department is made stronger by hiring and promoting faculty who will challenge existing precepts and commit to progress leads only to an environment of defensiveness. I offer these ideas based on the comments, as well as the research of others previously cited.

1. First, let's agree that any department, school, or college that does not weed out its bullies will forever face irrational, irreconcilable biases within its faculty that dampen team spirit and affect every element of teaching, research, and service. Bullying can take various forms, but they are at least consistent in the application of far and threats. Department heads must at least neutralize these characters. If the bully is the department chair, then the faculty must find a way, either through outside mediation or a forceful appeal to the dean, to bring the situation under control.

2. The online academic world - whether it is in an academic commons, clouds, or $e$-reserves—-has not created new rules. It has revealed how the rules we have clung to in the past are more irrelevant than they were when they were created. Exchanging an anonymous "peer" faculty for the Crown or the Church as taskmasters and judges of a professor's worth is an improvement. However, the cure is not without its faults. Every tenure review must be based on sound arguments, arguments that must themselves withstand the rigorous examination by other peers. A professor's work should be subjected to the most energetic 
reviews, the most penetrating examinations. But the exercise could be improved with a more open participation. This could be accomplished by increasing the committee of review, or by creating a review of the reviews themselves. Both or either of these could be accomplished easily through the use of online technology already available to all tenure committees.

\section{Evaluate the work, not the number.}

Consider this, should the singular work of Einstein in outline his Theory of Relativity be enough to earn him tenure in at physics department in the world. In hindsight, of course. Was the unwillingness of those universities who refused to hire this genius based on anything other than tradition, protocol, or a myriad of other false barriers? Numbers are wonderful things. But they are not the only measure of a faculty's worth to academia. They certainly are the easiest measure. And where is it written that a faculty person who publishes six articles in Journalism and Mass Communication Quarterly is immeasurably superior to one that publishes only five in same said journal? Or that twelve publications in a less lofty journal are of less value than the six in JMCQ? It takes time, but the work must be carefully measured to measure the worth of the researcher. The trouble is, of course, that some faculty_-even within the same department—are researching areas wholly unknown to their colleagues.

4. Tenure meetings should include more than just the tenure committee. 
Department politics are virtually unavoidable. The mere appearance of a decision driven by politics is so damaging that it renders any hope for the truly errant researcher to find the right path. This can be resolved by including reviewers outside the school. Those schools willing to fly in the face of Kant might even consider including reviewers outside the field, perhaps even outside of social sciences, in the case of mass communications. True, reviewers from engineering very likely would apply standards foreign to the social sciences. But a wise committee would take this into account and weight the comments made for their insightful value rather than their dogmatic details.

\section{Tenure meetings should not be anonymous.}

This is a difficult hurdle for almost all tenure committees. The sense is that, somehow, being free to comment without being identified to the candidate would render more honest appraisals. Yet, negative comments would likely be couched in more positive terms if names were attached. And, if the school offered mid-tenure reviews, as most do, the comments might (and ought to) lead to further interaction and mentoring. If any rule should drive a tenure committee, it should be that a bad researcher rendered into a good researcher is far better than a dismissal. This especially true in schools that offer little or no tenure mentoring to help fledgling academics learn the ropes of publishing. If the master's degree is intended to ensure we have a good researcher, the doctoral process certainly should be all about increasing the likelihood that the candidate will create valued, publishable research. While both of these tenants are debatable, it cannot be 
argued that a school hires an assistant professor with the hope that the assistant will blossom into an associate.

\section{Mentoring for tenure success.}

It is inexcusable that any school should have assistant professors floundering in the dark about what is required for tenure. It is inexcusable that any corner of academia has allowed the process to overcome the purpose. We can all debate what the tenure process is intended to produce, but the wise among us would certainly agree it not to produce candidate who can past artificial standards. The idea of allowing flexibility to ensure no worthy candidates are lost is noble. But without an engaged mentor, it is so easily can slip into darkness, leaving the candidate in constant fear of defeat without any certainty of how to avoid disaster. Nothing is so fearful for a tenure candidate than defeat. And, while other institutions might be willing to accept the "failed" candidate, the denial would create a scar not easily forgotten. It is the sort of event that can, and likely has, crushed promising researchers and teachers. And is so unnecessary. An active mentor can guide the candidate by offering lucid, honest appraisals and suggestions, starting on the first day of the hire.

\section{Mentoring for teaching success.}

It is not unusual for mass communication programs to restrict their doctoral students from teaching. As it was explained to me by my mentor in graduate school, "parents don't spend their money to send their children here to 
have them taught by a graduate student." Thus, many new hires are novices in the classroom. Add to this the witless use of student evaluations alone (yes, it is an easy measure to employ), and you have a recipe for failure. Some universities specifically bar the use of student evaluations as the sole guide. As noted in the Kansas State University faculty handbook (section C34.2):

Student ratings should never be the only source of information about classroom teaching. Departments or units should be encouraged to develop a comprehensive, flexible approach to teaching evaluation, where several types of evidence can be collected, presented and evaluated as a portfolio. Peers, administrators, and other appropriate judges also can offer useful insights about a faculty member's teaching performance. Peer evaluation, defined as a critical review by colleagues knowledgeable of the entire range of teaching activities, can be an important component of the university's teaching evaluation program since peers are often in the best position to interpret and understand the evidence and place it in its proper academic context.

This very wise statement does not preclude a department from relying almost exclusively on student evaluation, which as a friend of mine once noted is asked of a population at a time of tremendous pressure, and, at times, feelings of anger, fear, and hostility. Additionally, any department interested in establishing something more than whether a tenure-track faculty member is a "good teacher" 
should be actively engaged in insuring that this good teacher is actually created. Few are born to teach; but many can become good teachers. Moreover, tenured faculty should be more than reporters at the scene of a disaster. They are in a position to prevent the disaster, by again offering engagement, advice, and observation. From visiting the classroom to setting regular meetings (especially early in the first semester), the tenured mentor can sound out the new professor, provide real guidance, and help not only the tenure candidate but also the students being taught.

8. Outside comment on a professor's work.

This may be the hardest task for any tenure committee: the crossing of department or college barriers. Seeking outside comment of works, such as books, is commonplace in publishing (Plater 1995, 42). It offers the writer a fresh perspective, and, with a tenure committee, a chance to find out what was missed. Did the candidate excel in service? Did the candidate publications have a positive impact outside the realm of mass communication? Were non-majors taking survey courses (often taught by first-year professors) especially impressed, impressed enough to comment regarding the class to their advisors? Without wishing to appear rude, there is intelligent life outside the bounds of any department, contrary to what some faculty may believe. Research developed in a manner not familiar should not automatically be invalidated. Tenure committees should avail themselves of the opinion of others who work at a distance from the cross currents of internal strife. All of us have heard of or witnessed situations where faculty at 
odds with each other may take their frustrations out on tenure candidates. As unacceptable as we may find this, it happens nonetheless.

9. Re-evaluation of what constitutes scholarly research.

This is another touchy issue. In recent years, the term "scholarly research"—at some universities_-has come to include activities seemingly foreign to (some) "pure" academic researchers. Such activities might include editing an academic journal, working on a non-grant generating project that benefits the university, acting as a reviewer for several scholarly journals, or providing leadership in teaching excellence. As I have noted elsewhere, in an academic world that is rapidly become more and more global by the second, the need for more outreach and guidance to educators everywhere is not only good, it cannot be replaced by text books or software programs. Teachers learn best from good teachers. Researchers learn best from good researchers. Valuing these actives, including work on new online journal_admittedly a personal issue for me-is not somehow degrading the concept of tenure. It is, instead, recognizing that scholarship in the new century is more than generating a significant $p$ in a research paper within a local, isolated room. We are, or should be, a global faculty.

10. Stay engaged.

We all have ridiculous schedules. We all take on more than we should. This is a given. It is not, however, an excuse for not being active in all phases of 
our department, school, college, university, and academia. We all, by and large, know this. This needs to be extended to new faculty, many of whom come from industry, where — trust me —-the rules are far different. Bottom line, no tenuretrack professor should ever feel lost, uncertain, or fearful of their success because of some sort of tenure committee rationale that "I did it, they should be able to do it." Just because we were not provided adequate leadership and guidance, it should not follow that we pass this along to those who follow. Right-headed thinking argues we want those who follow us to be better than we are. We must be actively involved and stay actively involved if this is to happen.

\section{Bibliography}

Abandoning Print. "Abandoning Print, Not Peer Review." Inside Higher Ed. http://www.insidehighered.com/news/2008/02/28/open (accessed December 5, 2010).

Aylesworth-Spink, Shelley. "Getting Jobs with a Doctorate - Career Options for PhD Graduates." Suite101.com. http://www.suite101.com/content/getting-jobs-with-adoctorate---career-options-for-phd-graduates-a201804 (accessed December 5, 2010).

Bradley, S. G. Managing the Tenure Process. The Lab Manager Magazine, July 31, 2006. 1 (accessed October 10, 2010).

Stephen L. Carter, "Academic Tenure and "White Male" Standards: Some Lessons from the Patent Law." Yale Law Review 100, no. 2065 (May 1991, 1991) 2065-2085.

David S. Clark, "The Medieval Origins of Modern Legal Education between Church and State," American Journal of Comparative Law 35, no. 44 (1987) 653-719. 
John M. Connolly, "The Academy's Freedom, the Academy's Burden," The NEA Higher Education Journal 16, no. 1 (Summer, 2000) 69-82.

Dad, Dean. "Transparency and Reciprocity." Confessions of a Community College Dean. http://www.insidehighered.com/blogs/confessions_of_a_community_college_dean/tr ansparency_and_reciprocity (accessed October 10, 2010, March 27).

Richard T. De George, "Ethics, Academic Freedom and Academic Tenure," Journal of Academic Ethics 1, (2003) 11-25.

J. Stephen Ferris and Michael McKee, "Measuring Academic Potential: A Case for Academic Tenure and Process," Carleton Economic Papers 02-06, (January, 2002) $1-30$.

Ralph F. Fuchs, "Academic Freedom—Its Basic Philosophy, Function, and History," Law and Contemporary Problems 28, no. 3 (Summer, 1963) 431-446.

Fuhrman, Susan and Marvin Lazeson. The Public Schools. Institutions of American Democracy., edited by Kathleen Hall Jamieson. New York: Oxford University Press, 2005.

Claudia Goldin and Lawrence F. Katz, "The Shaping of Higher Education: The Formative Years in the United State, 1980 to 1940," Journal of Economic Perspectives 13, no. 1 (Winter, 1999) 37-62.

Ron Halse and Gary L. Lilien, "The Ombudsman: Academic Research in MS/OR: Science Or Trivial Pusuit," Interfaces 16, no. 3 (May-June, 1986) 41-48. Hamilton, Neil W. Academic Ethics: Problems and Materials on Professional Conduct and Shared Governance. Westport, CT: Anerican Council on Education/Praeger, 2002. 
Hannam, James. "Medieval Science, the Church, and Universities." Bede's Library. http://www.bede.org/university.htm (accessed October 11, 2010).

B. He, M. Patel, Z. Zhang, and K. C. -C Chang, "Accessing the Deep Web: A Survey," Communications of the ACM 50, no. 5 (2007) 95-101.

Hofstadter, Richard and Walter P. Metzger. The Development of Academic Freedom in the United States. New York: Columbia University Press, 1955.

Joughin, Louis, ed. Academic Freedom and Tenure. Second ed. Madison, WI: University of Wisconsin Press, 1969.

Keast, William R. and John W. Jr Macy, eds. Faculty Tenure. London: American Association of University Professors, Association of American Colleges and JosseyBass, Inc., 1973.

Dirk Lawandowski and Phillipp Mayr, "Exploring the Academic Invisible Web," Library Hi Tech 24, no. 4 (April 28, 2006) 529-539.

Madhaven, Jayant, Loredana Afanasiev, Lyublena Antova, and Alon Halevy. "Harnessing the Deep Web: Present and Future." Asilomar, CA, US, January 4-7, 2009.

Michael S. McPherson and Morton Owen Schapiro, "Tenure Issues in Higher Education," Journal of Economic Perspectives 13, no. 1 (Winter, 1999) 85-98.

Metzger, Walter P. Academic Tenure in America: A Historical essay in Faculty Tenure a Report and Recommendations for the Commission on Academic Tenure in Higher Education. San Francisco, California: Jossey-Bass Publishers, 1973.

Office of the President. "Strategic Plan, Phase II: 2009-2013." Oregon State University. http://oregonstate.edu/leadership/strategicplan/ (accessed December 5, 2010). 
Perlmutter, David D. "Professionalize Promotion and Tenure." The Chronicle of Higher Education, February 18, 2010, 2010.

William Plater, "Future Work," Change 27, no. May/June (1995) 22-33.

William Plater, "The Twenty-First Century Professoriate," Academe 94, no. 4 (2008) 3540.

Post, Robert. "Academic Freedom: Its History and Evolution within the UC System." Berkeley, CA, Academic freedom Forum, June 11, 2003.

Resnik, David B. "What is Ethics in Research and Why is it Important?" National Institute of Environmental Health Sciences: National Institutes of Health. http://www.niehs.nih.gov/research/resources/bioethics/whatis.cfm (accessed November 1, 2010).

Sass, Steven A. The Pragmatic Imagination. Philadelphia, Pennsylvannia: University of Pennsylvannia Press, 1982.

Michael M. O. Seipel, "Assessing Publication for Tenure," Journal of Social Work Education 39, no. 1 (Winter, 2003) 79-88.

Stevenson, Adlai. "Book of Famous Quotes." Haythum R. Khalid. http://www.famousquotes.com/author.php?aid=6974 (accessed October 10, 2010).

Tenured Radical. "Tenure, Tenure: Who's Got the Tenure?" Tenured Radical 2.0. http://tenured-radical.blogspot.com/2008/04/tenure-tenure-whos-got-tenure.html (accessed October 10, 2010, April 2).

Justin Thorens, "Liberties, Freedom and Autonomy: A Few Reflections on Academia's Estate," Higher Education Policy 19, (2006) 87-110. 
Verrier, David A. "On Becoming Tenured: Acquiring Academic Tenure at a Research University. ASHE Annual Meeting Paper." Minneapolis, MN, Association for the Study of Higher Education, November 1, 1992, 1992.

Wilson, Robin. "The Ivory Sweatshop: Academe is no Longer a Convivial Refuge." The Chronicle of Higher Education, July 25, 2010, 2010.

C. A. Wright, "The Academic Library as a Gateway to the Internet: An Analysis of the Extent and Nature of Search Engine Access from Academic Library Home Pages " College \& Research Libraries 65, no. 4 (July, 2004) 276-286. 